\title{
Towards a Common Understanding: A Revision of Fourche Maline Chronology in Oklahoma
}

Luther J. Leith

Unknown

Follow this and additional works at: https://scholarworks.sfasu.edu/ita

Part of the American Material Culture Commons, Archaeological Anthropology Commons, Environmental Studies Commons, Other American Studies Commons, Other Arts and Humanities Commons, Other History of Art, Architecture, and Archaeology Commons, and the United States History Commons

Tell us how this article helped you.

This Article is brought to you for free and open access by the Center for Regional Heritage Research at SFA ScholarWorks. It has been accepted for inclusion in Index of Texas Archaeology: Open Access Gray Literature from the Lone Star State by an authorized editor of SFA ScholarWorks. For more information, please contact cdsscholarworks@sfasu.edu. 
Towards a Common Understanding: A Revision of Fourche Maline Chronology in Oklahoma

\section{Creative Commons License}

\section{(c) (1) (8)}

This work is licensed under a Creative Commons Attribution-NonCommercial 4.0 International License 


\title{
TOWARDS A COMMON UNDERSTANDING: A Revision of Fourche Maline Chronology in OKLAHOMA
}

\section{Luther J. Leith}

\begin{abstract}
Answering the question of what Fourche Maline is has long been hampered by lack of consensus on the terminology and chronology within the ancestral Caddoan area of the four corners area of southeast Oklahoma, southwest Arkansas, northeast Texas and northwest Louisiana. To address this problem an evolution of the Oklahoma concept of Fourche Maline is presented, and developing a new chronology based on seriation of temporally sensitive artifact categories is discussed. It is concluded that Fourche Maline is a solely Woodland period culture, with a chronology that makes identifying changes over time possible. This conclusion will facilitate the understanding of Fourche Maline within the Caddoan homeland.
\end{abstract}

\section{Introduction}

One of the major factors inhibiting a regional understanding of ancestral Caddoan speaking people stems from incompatible conceptualizations of Fourche Maline due to terminology and chronology. For example the term Fourche Maline can mean many things with out a qualifier, such as: creek, drainage, culture, focus, phase etc. Also in Oklahoma there has long been the tendency to include cultures spanning the Late Archaic through emergent Mississippian periods as being Fourche Maline.

The majority of researchers in Oklahoma have seen Fourche Maline as essentially an Archaic/Woodland transitional culture (Bell and Baerreis 1951; Bell 1953, 1980; Galm 1981, 1984; Galm and Flynn 1978; Proctor 1957; Sharrock 1960). Schambach (2002) argues that Fourche Maline is a solely Woodland period culture. It is interesting to note that Orr (1952) held a similar view of Fourche Maline in Oklahoma. Orr considers Fourche Maline to be Early to Middle Woodland in age.

Another major problem with Oklahoma's concept of Fourche Maline is the roughly 1,000 year-long "phases." Schambach $(1982 ; 1998 ; 2002)$ has been able to refine the chronology in Arkansas to more manageable phases (in line with Willey and Philips 1958). His concept and chronology has become the standard concept of Fourche Maline in the states neighboring southeast Oklahoma (Arkansas, Texas and Louisiana).

To better understand the problems with the concept of Fourche Maline, we begin with a review of the evolution of the concept of Fourche Maline in Oklahoma. In order to address the incompatibility of much of the Oklahoma concept of Fourche Maline, a seriation of temporally sensitive artifacts was conducted. This seriation was then used to refine Oklahoma's Fourche Maline chronology. The revised concept and chronology will make regional comparison and discussion of Fourche Maline easier.

\section{Evolution of the Concept of Fourche Maline in Oklahoma}

The history of the concept of Fourche Maline begins with Moore's 1912 and Harrington's 1917 expeditions up the Red River in Arkansas (Harrington 1920; Moore 2003). These early archaeologists were looking for beautiful, finely decorated, pottery and other material-culture. However, Moore and Harrington did excavate sites that fit Bell and Baerreis' (1951) definition of Fourche Maline traits (black-middens located near streams). Little attention was paid to this cultural manifestation during Moore and Harrington's earlier excavations, because these black-midden mounds had very few beautiful pots and other distinctive artifacts. 
Major research in Oklahoma did not begin until the late 1930s and early 1940s as part of the Works Progress Administration (W.P.A.) excavations (Kreiger 1947; Newkumet 1940; Orr 1946). At this time, archaeologists were attempting to develop a cultural chronology for southeastern Oklahoma. Research continued off and on in Oklahoma up through the end of the 20th century (Bell 1953; Bell and Baerreis 1951; Davis 1961a, 1961b; Galm 1981, 1984; Galm and Flynn 1978; Guilinger 1971; Orr 1952; Picarella 1999; Proctor 1957; Sharrock 1960; Vehik 1982a, 1982b), although there was a significant research gap between the early 1980s and 2000. Most of the excavations conducted at Fourche Maline sites have focused on the midden mound with very little off-mound investigation. Research primarily continued to develop chronology, cultural-trait lists, and some early regional syntheses (e.g., Galm 1984; Orr 1952; Wyckoff 1980), but it is important to point out that there has been considerable bio-archeological research, such that we know more about the physical anthropology of the Fourche Maline people than their material culture (Burnett 1990a, 1990b; Burns 1994; Harmon and Rose 1989; Powell and Rogers 1980; Rose and Burnett 1990; Rose and Harmon 1989; Rose et al. 1999a, 1999b; Rowe 2009).

Galm (1984) following Bell's (1980) call for re-conceptualizing Fourche Maline attempted to clarify the terminology and bring the concept of Fourche Maline up to date. He redefined the Fourche Maline Focus as two phases: the Late Archaic (Wister phase) and the Woodland period (Fourche Maline phase) (Galm 1984). Schambach (2002) argues that Galm inappropriately named the Fourche Maline phase as he had defined Fourche Maline as a cultural unit (basically a tradition following Willey and Phillips 1958) two years earlier (Schambach 1982). The problem here is one of competing grey literature as Galm and Flynn (1978) had already published definitions of the Wister and Fourche Maline phases, which would be five years before Schambach's 1982 definition.

However, Schambach's conceptualization of Fourche Maline as a cultural tradition has gained acceptance and is currently used in Arkansas and Texas (Schambach 1982, 1998, 2002; Bruseth 1998). A second problem with Galm's (1984) definition of the Fourche Maline phase is its length. Galm has Fourche Maline spanning the period 300 B.C. to A.D. 800, which is over 1000 years. Willey and Phillips (1958) define a phase as an archaeological unit that is distinct from units similarly conceived and spanning a relatively brief period of time. Galm's phase fits better as a sub-period in its duration and needs to be refined into units that are more in line with Willey and Phillip's definition. Along with the need to refine the Fourche Maline phase in Oklahoma, we need to bring the Oklahoma concept of Fourche Maline into line with the Schambach (2002) concept of Fourche Maline. Researchers in Arkansas, Texas, and Louisiana have defined Fourche Maline as a Woodland period society who were the ancestors of the modern Caddo people.

Many sources present information on the material culture of the Fourche Maline people (Bell 1953; Bell and Baerreis 1951; Davis 1961a, 1961b; Galm 1981, 1984; Galm and Flynn 1978; Guilinger 1971; Orr 1952; Picarella 1999; Proctor 1957; Sharrock 1960; Vehik 1982a, 1982b). Presently Galm (1984) tends to be considered the standard definition of Fourche Maline in Oklahoma. As mentioned earlier, Galm replaced the old Fourche Maline Focus with the Arkansas Valley Caddoan Formative, which is made up of Archaic (Wister phase) and Woodland (Fourche Maline phase) occupations (Galm 1984). A summary of Galm's phases follows.

\section{The Wister Phase}

Galm (1984: 210-213) defines the Wister phase as Late Archaic occupations in the Fourche Maline valley dating from roughly 300 B.C. to around A.D. 300. Pre-pottery assemblages identify this phase. Among the artifacts are contracting stem (Gary) projectile point/knives with some corner-notched, expanding stem points. This phase also contains ground stone objects (handstones, boat stones, pendants), bone tools (awls, pins, atlatl hooks, fish hooks) and shell beads, discs, and pendants (Galm 1984: 210-213). This assemblage conveys clues 
that the subsistence strategy was hunting, gathering and fishing. Long distance trade is witnessed by occasional exotic raw materials such as copper and marine shell (Galm 1984:210-213).

\section{The Fourche Maline Phase}

Galm (1984:213-216) defines the Fourche Maline phase as Woodland period occupations generally dating to around A.D. 300 to 800 . The important marker of this phase is a thick grog-tempered and mixed grog temper pottery of the Williams Plain and LeFlore Plain types. The artifact assemblage also contains contracting stem (Gary) points, fewer corner-notched dart points, and initial use of small corner-notched (Scallorn) arrow points, indicating a shift in hunting technology (Galm 1984:213-216). Also a variety of chipped-stone implements, such as hoes and double-bit axes, as well as continued use of ground stone and bone implements common during the Wister Phase (Galm 1984:213-216).

It is time to revise Galm's (1984) concept of Fourche Maline by refining the chronology. He alludes to material culture hallmarks that can and should be used to break what are essentially sub-periods into more manageable phases. An example is the adoption of the bow and arrow, which can and should represent a temporally diagnostic change in material culture. The refinement of the Fourche Maline chronology is a necessary first step in identifying what Fourche Maline is as it will avoid confusing temporal differences with spatial or social differences.

Several assumed temporally sensitive artifact types were chosen to refine the chronology. These were varieties of large contracting stem (Gary) points, arrow points, chipped-stone axe/hoes, and pottery (Williams Plain, Williams Boneware, and LeFlore Plain).

\section{Methodology}

In order to refine the Fourche Maline chronology I seriated select artifact classes from the J.W. Williams I site (34Lf24). This site's entire midden mound was excavated by the W.P.A. I recognize biases occur when using W.P.A. excavated sites because the methodology used was not as rigorous as modern field methods. But the Williams I site is the best excavated W.P.A. black-midden site in Oklahoma. It was excavated in arbitrary sixinch levels, and many of the artifacts have piece-plot references.

A total of three blocks of contiguous units were selected for the seriation. The primary seriation was conducted on a block of 13 contiguous $5 \times 5 \mathrm{ft}(1.5 \times 1.5 \mathrm{~m})$ units located near the center of the midden (Figure 1 ). These units were chosen to avoid burials because these intrusive features were hard to identify in the dark soil and cannot be controlled for using arbitrarily excavated levels. This sample also allows greater artifact counts and a greater diversity of artifact types that strengthen the seriation. The choice of contiguous units near the center of the midden mound was an attempt to alleviate problems associated with the contour of the mound. The units chosen should be comparable as they are near the apex of the mound and the difference in elevation is only around 0.07 in $(0.2 \mathrm{~cm})$ per horizontal foot $(30.5 \mathrm{~cm})$ between samples units.

Two other blocks of units; one near the eastern margin and one near the western margin, were selected to test the results of the initial seriation. Again, these were selected to avoid units containing burials (see Figure 1). The eastern sample consisted of $175 \times 5 \mathrm{ft}(1.5 \times 1.5 \mathrm{~m})$ units, and the western sample consisted of $195 \times 5 \mathrm{ft}$ $(1.5 \times 1.5 \mathrm{~m})$ units. It should be noted that there is close to one foot $(30.5 \mathrm{~cm})$ of elevation change between some of the units in these groups, which could affect the depths/levels from which artifacts are coming. Percentages were calculated on each of the artifact types by level. This was important in the seriation of the pottery because it addresses issues of minimum number of vessels by giving single sherds more weight. However, the use of percentages does mask some of the differences because each category is dependent on the others. This can lead to over-inflating some of the categories due to low counts. In order to address this issue a separate seriation 


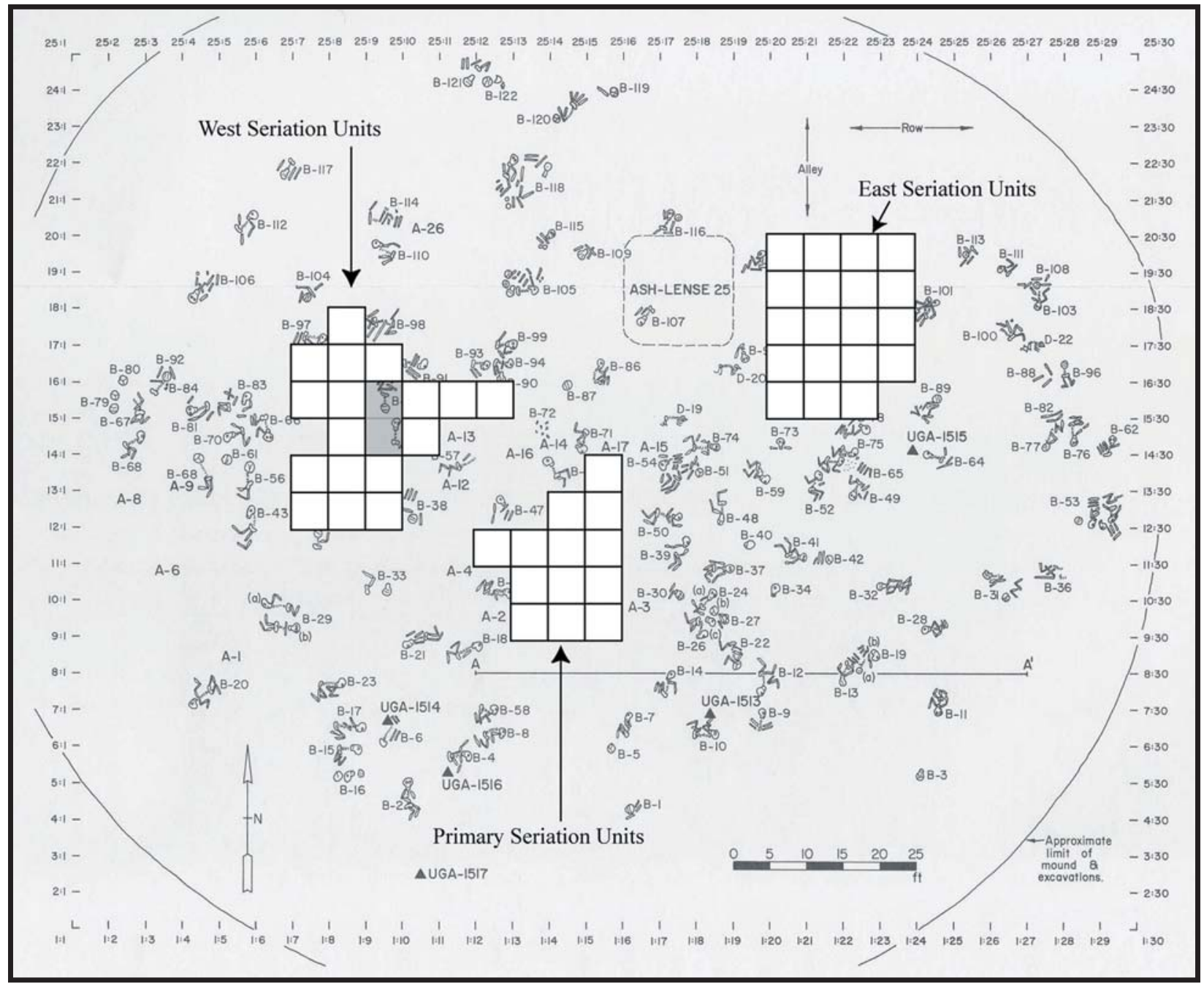

Figure 1. J.W. Williams I Map Showing the Location of Units used in the Seriation (grey units omitted).

Correspondence analysis was conducted using the JMP ${ }^{\mathrm{TM}}$ statistics program. Correspondence analysis is an exploratory data-analytic technique that is commonly used for seriation in archaeology (Baxter 2003:137). Basically correspondence analysis is a Principle Component Analysis for tables of counts that produces a graphical view of the structure of a table (basically a representation of the relationship between rows and columns allowing identification of the association between them) (Baxter 2003). The aim of a correspondence analysis is to suggest an ordering for the assemblage that has chronological interpretations (Baxter 2003:137138).

\section{Point Seriation}

Schambach (1982) identified three varieties of Gary points that he considered temporally sensitive (Table 1). These are variants gary, leflore, and camden (Figure 2). The defining features of these variants are the shape of the base, thickness and width.

To test Schambach's model, base shape (U or V shaped), thickness, and variety designations were recorded for the 213 contracting stem points from the 34Lf24 sample units. In addition to testing Schambach's Gary variants temporal sensitivity, counts of Archaic dart points and arrow points (with thickness for the arrow points) were also recorded. A seriation using correspondence analysis was performed on the three varieties of Gary, the generalized Archaic bifaces (including notched and straight stem forms) and arrow points. 
Table 1. Attributes and Variables of Schambach's (1982) Gary Point Varieties.

\begin{tabular}{|l|l|c|c|}
\hline \multicolumn{1}{|c|}{ Types } & \multicolumn{1}{|c|}{ Morphology } & $\begin{array}{c}\text { Thickness } \\
\text { (mm) }\end{array}$ & $\begin{array}{c}\text { Mean Thickness } \\
\text { (mm) }\end{array}$ \\
\hline Gary gary & Lobate stem, convex edges rounded base, U shaped base & $7-13$ & $10-11$ \\
\hline Gary leflore & Stem narrower in proportion to blade, V-shaped base & $4-14$ & $7-8$ \\
\hline Gary camden & $\begin{array}{l}\text { Narrow point, weakly shouldered to no shoulder, blade only } \\
\text { slightly wider than leflore stems, V-shaped base }\end{array}$ & $4-14$ & 7 \\
\hline
\end{tabular}

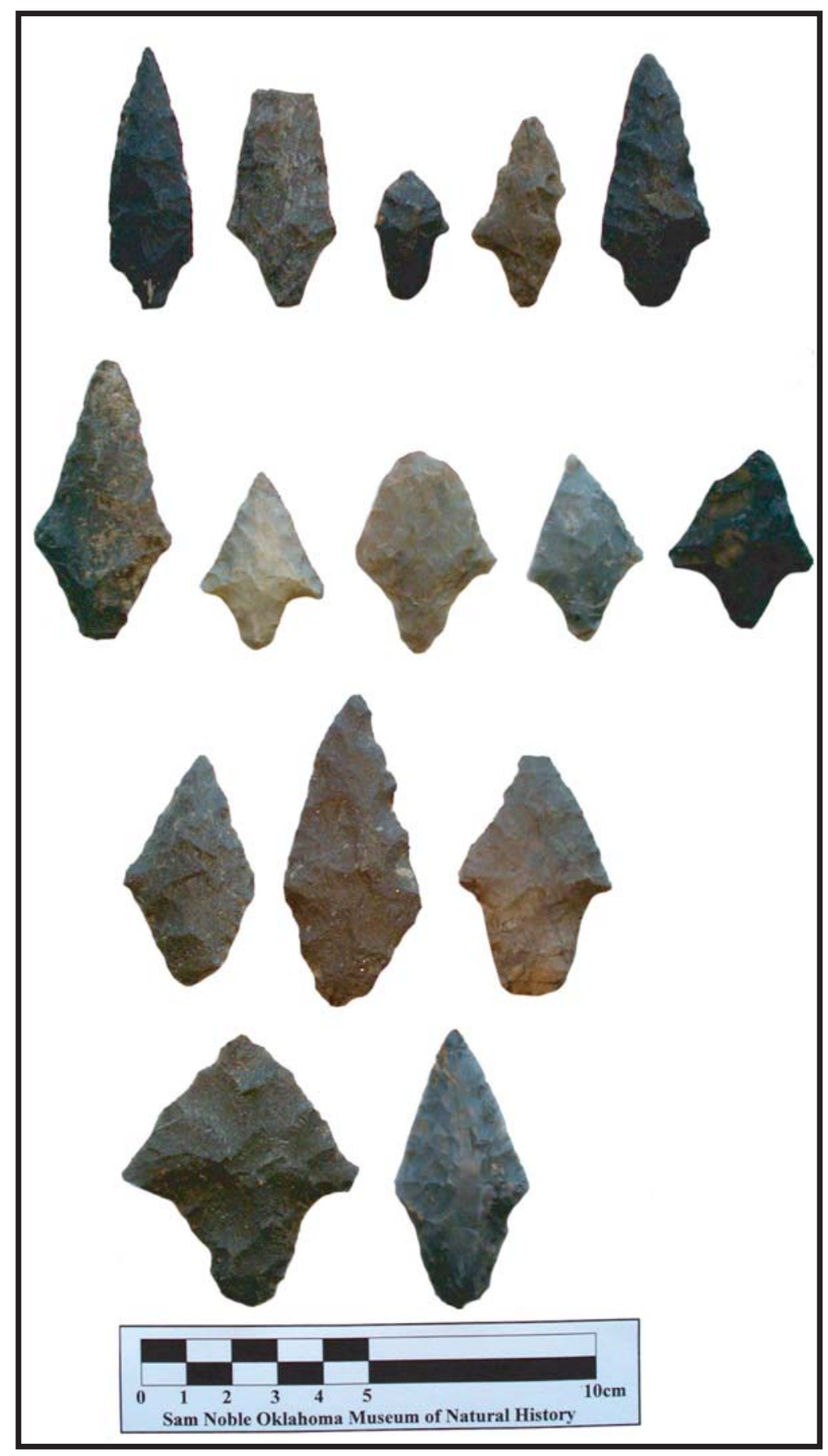

Figure 2. Gary Varieties from J.W. Williams I (top gary, middle leflore, bottom camden). 


\section{Axe/Hoe Seriation}

Chipped-stone axe/hoes are common to the Wister and Fourche Maline phases. There were only 135 chipped-stone axe/hoes from the entire 34Lf24 midden. All the axe/hoes from the site were considered because the overall count was low. These tools were identified as stemmed, double-bitted, or indeterminate. The indeterminate, surface finds and burial units were omitted. Counts were recorded by level for both the stemmed and double-bit varieties, and a seriation was then performed.

\section{Pottery Seriation}

Galm (1984) states the diagnostic pottery wares associated with Fourche Maline people are Williams Plain, and LeFlore Plain. He also notes that the addition of bone to the temper of Williams Plain looks to be a later trait (Galm 1984). Again the Williams site was chosen for seriation as the pottery assemblage has had research conducted on it (Irvine 1980), which helped with initial identification of pottery types. The same units chosen for the point seriation were used for the pottery seriation. The attributes and variables recorded were temper, thickness, and presence/absence of burnishing. These were used to identify four specific wares or types and one general pottery category. These were: Williams Plain, Williams Boneware, LeFlore Plain, Woodward Plain, and Indeterminate Decorated (Table 2 and Figures 3 to 5). These types were then seriated using correspondence analysis.

Table 2. Fourche Maline Pottery Types.

\begin{tabular}{|l|l|l|l|l|}
\hline Pottery Type & Temper & Thickness & Surface Treatment & Forms \\
\hline $\begin{array}{l}\text { Williams Plain } \\
\text { Brown 1971) }\end{array}$ & $\begin{array}{l}\text { predominately } \\
\text { grog, with some } \\
\text { mixed temper }\end{array}$ & $\begin{array}{l}5.9-17.8 \mathrm{~mm} \\
\text { mean } 7.7 \mathrm{~mm} \\
\text { generally }>1 \mathrm{~cm}\end{array}$ & $\begin{array}{l}\text { smoothing, wiping, } \\
\text { some burnishing }\end{array}$ & $\begin{array}{l}\text { simple bowl, globular bowl, cup, } \\
\text { restricted jar, barrel shaped jar, with } \\
\text { some miniature versions }\end{array}$ \\
\hline $\begin{array}{l}\text { Williams Boneware } \\
\text { (Proctor 1957) }\end{array}$ & grog-bone & $\begin{array}{l}\text { likely same as } \\
\text { Williams Plain }\end{array}$ & $\begin{array}{l}\text { smoothing, wiping, } \\
\text { some burnishing }\end{array}$ & likely same as Williams Plain \\
$\begin{array}{l}\text { (Proctliams Incised } 1957, \text { Brown } \\
\text { 1971) }\end{array}$ & $\begin{array}{l}\text { predominately } \\
\text { grog, with some } \\
\text { mixed temper }\end{array}$ & $\begin{array}{l}\text { Wikely same as } \\
\text { Williams Plain }\end{array}$ & $\begin{array}{l}\text { smoothing, wiping, } \\
\text { some burnishing }\end{array}$ & likely same as Williams Plain \\
\hline $\begin{array}{l}\text { LeFlore Plain (Brown } \\
\text { 1971) }\end{array}$ & grog-grit & $\begin{array}{l}4.2-9.8 \mathrm{~mm} \\
\text { mean } 6.19 \mathrm{~mm} \\
\text { generally } \\
<1 \mathrm{~mm}\end{array}$ & usually burnished & $\begin{array}{l}\text { simple bowl, globular bowl, restricted } \\
\text { orifice globular bowl, carinated bowl, } \\
\text { gourd-section bowl, jars, narrow- } \\
\text { mouthed bottle, wide mouthed bottles }\end{array}$ \\
\hline $\begin{array}{l}\text { Woodward Plain } \\
\text { (Brown 1971) }\end{array}$ & shell & $\begin{array}{l}5-11.2 \mathrm{~mm} \\
\text { mean } 7.48 \mathrm{~mm}\end{array}$ & burnished & $\begin{array}{l}\text { simple bowls, independent restricted } \\
\text { jars, wide-mouthed bottle, seed jar }\end{array}$ \\
\hline
\end{tabular}




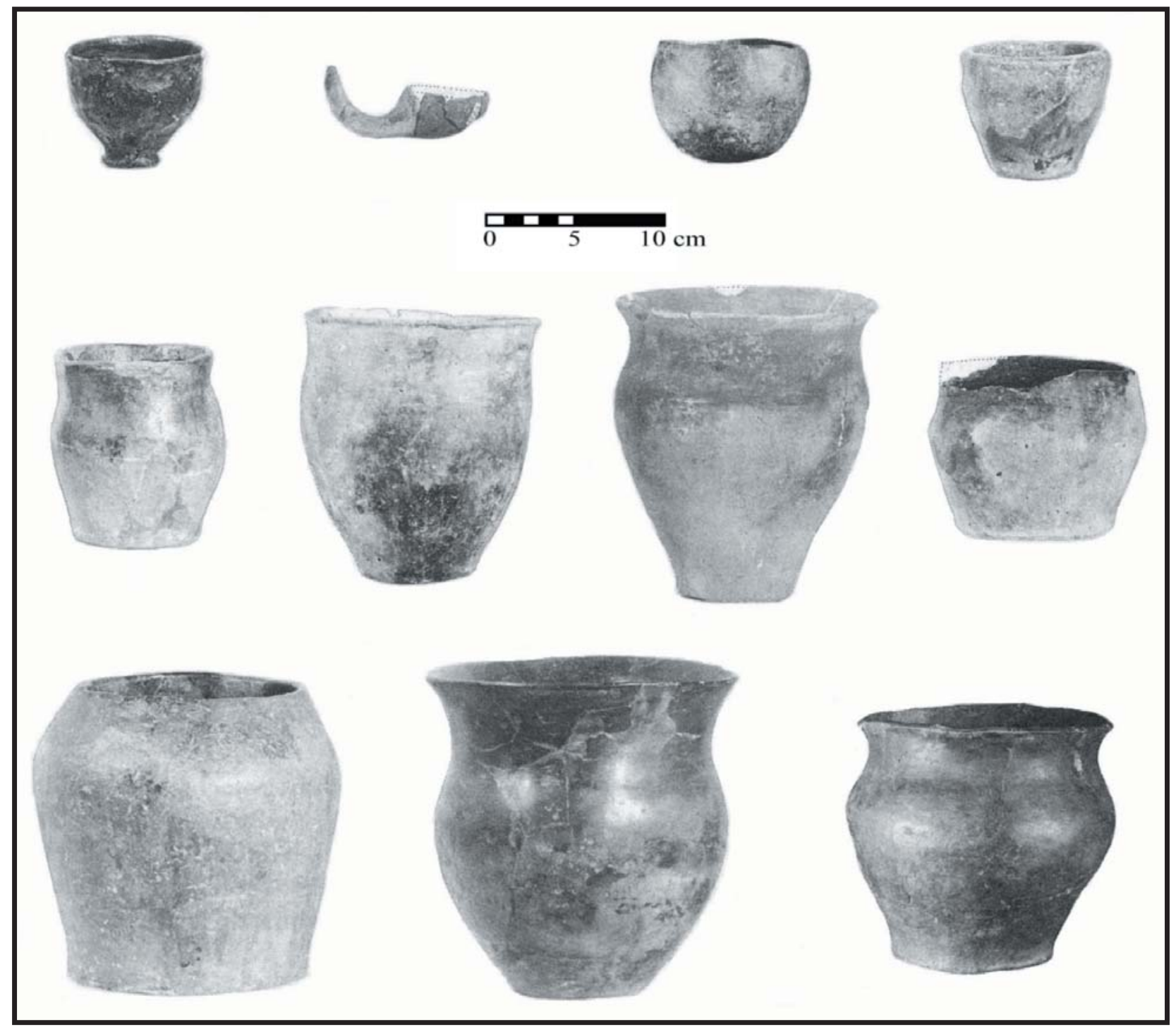

Figure 3. Williams Plain Vessel Forms from Spiro (adapted from Brown 1971). 


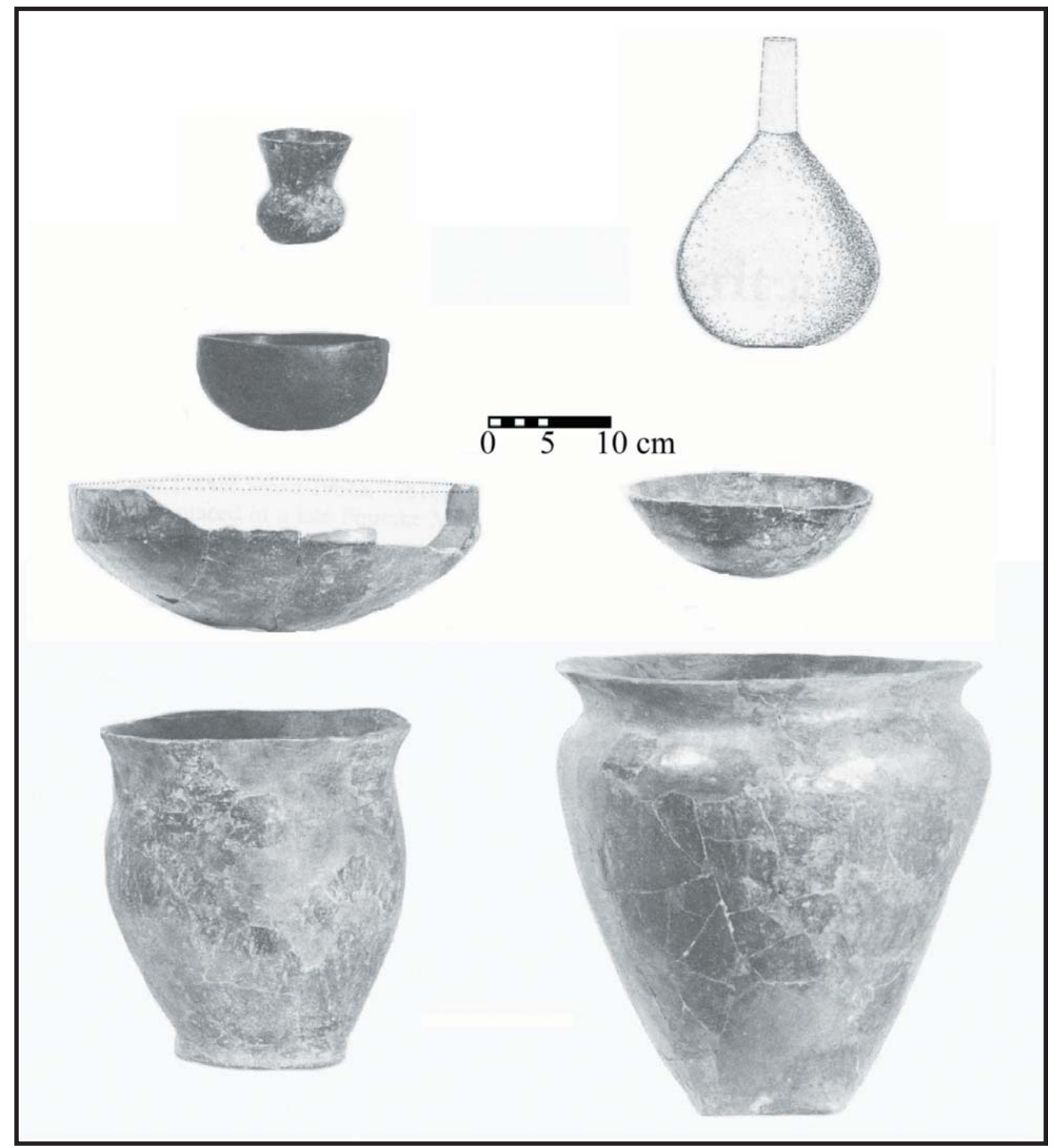

Figure 4. LeFlore Plain Vessel Forms from Spiro (adapted from Brown 1971). 


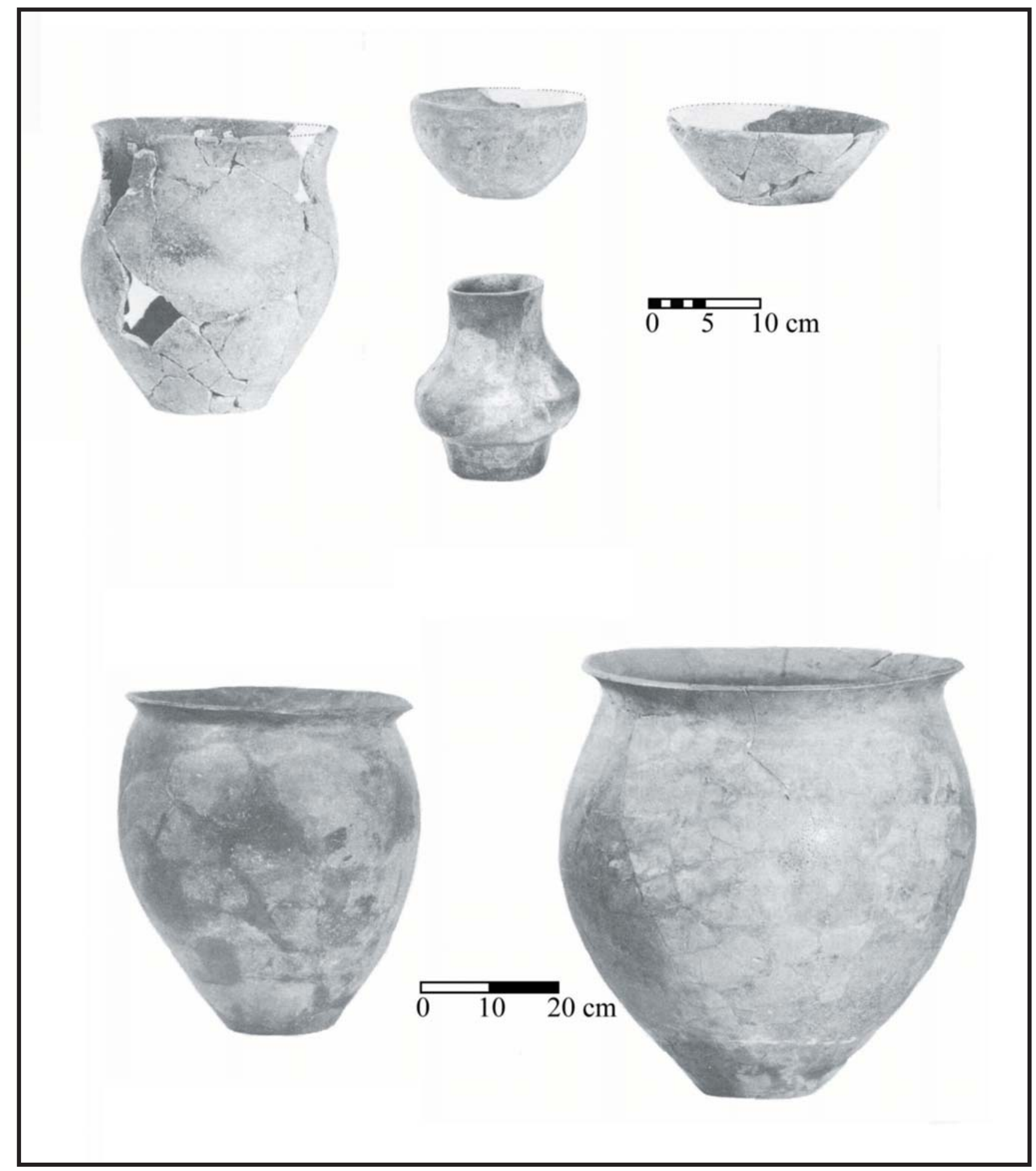

Figure 5. Woodward Plain Vessel Forms from Spiro (adapted from Brown 1971). 


\section{Building a Fourche Maline Chronology}

To initiate building a chronology I began by testing Schambach's (1982) temporally sensitive varieties of Gary points. Figure 6 shows the results of the correspondence analysis based on percentage by level. Baxter (2003) states that 'horseshoe'-shaped plots in which the ordering can be read around the horseshoe are often considered a good seriation. The direction in which the plot is interpreted must come from outside information. In this case we know which way to read the findings because we know the order of the levels excavated.

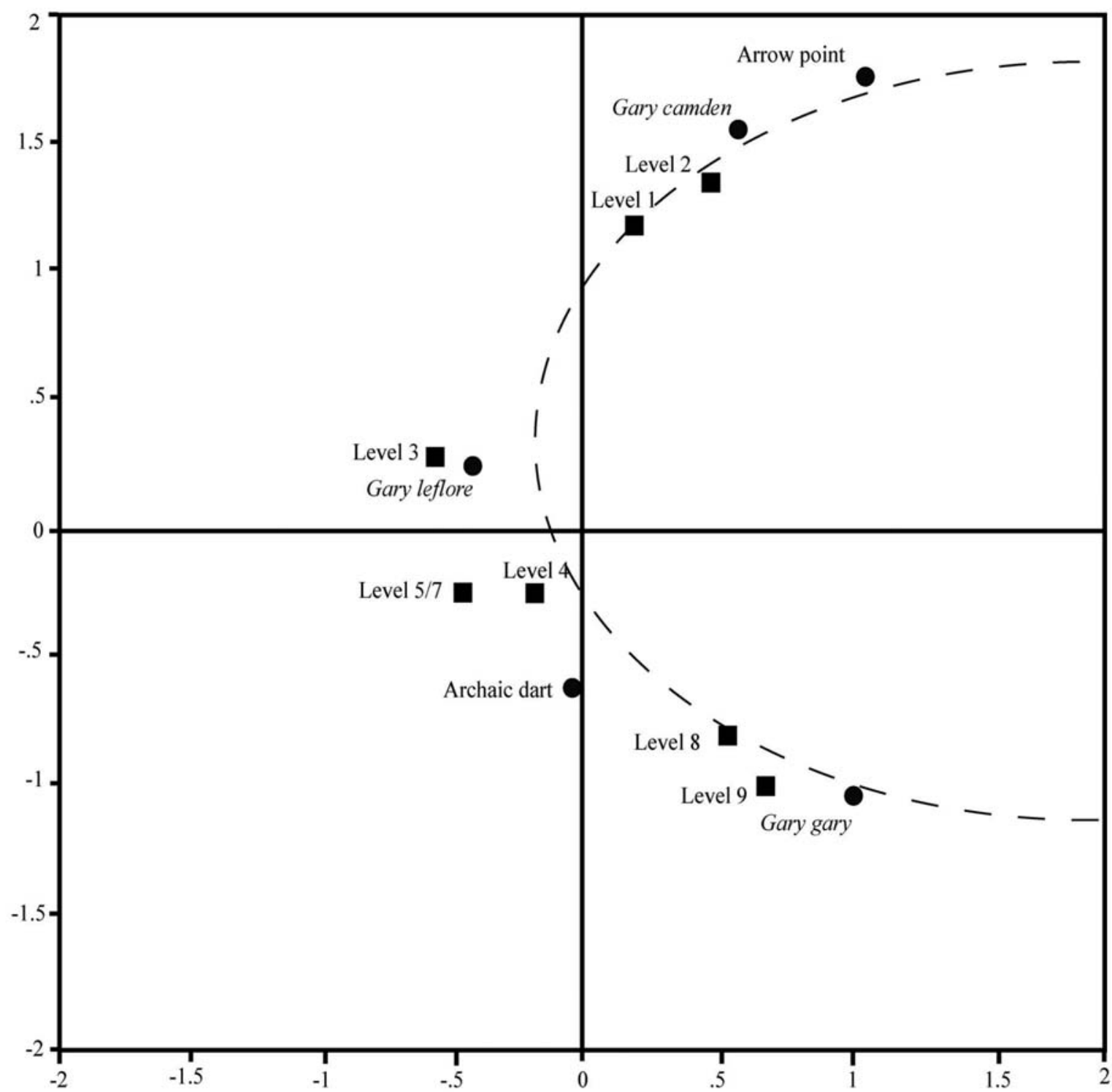

Figure 6. Results of the Williams I Point Type Correspondence Analysis (note the strong horseshoe-shaped curve).

The findings do indicate that Schambach's Gary varieties are temporally sensitive. The strong horseshoe shape, following Baxter (2003), indicated a good seriation. Reading the horseshoe from bottom right (oldest) to top right (youngest) support Schambach's temporal hypothesis (Figure 7). I have also presented Fordian battleship graphs to help with the interpretation of the correspondence analysis. 


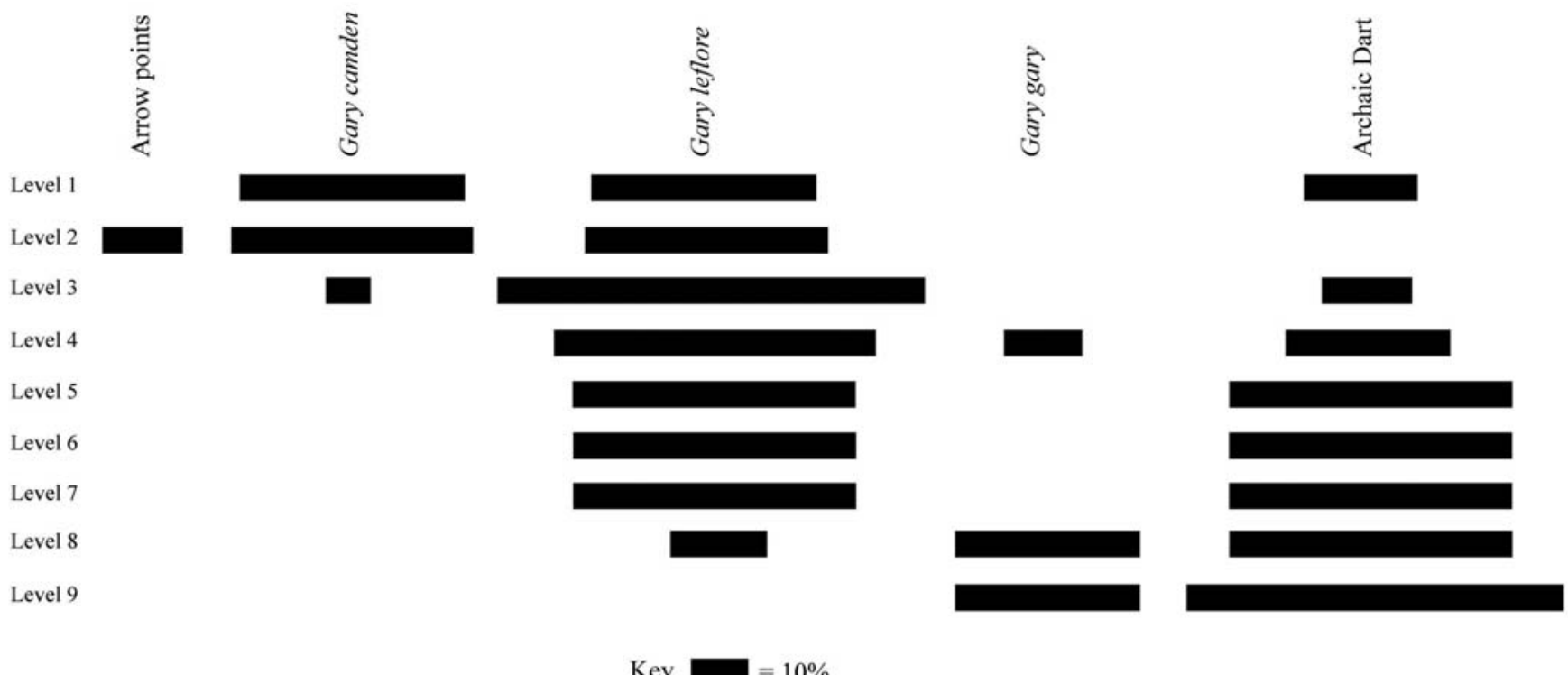

Figure 7. Battleship Graph of the Williams I Seriation of Point Percentages by Class.

The Gary gary variety appears to be an early variety which peters out around Level 6 (Figures 8). The leflore variety appears long-lived showing up at around Level 8 and continuing throughout the rest of the levels. The camden variety is the smallest (and thinnest) variety and appears late in the sequence (around Levels 2 and 3). Gary camden may be a transitional dart/arrow point type as Schambach (1998:128) has suggested. The raw counts for the points shows essentially the same results, but the Archaic dart points are not as over-inflated in relation to the other points due to the use of percentages.

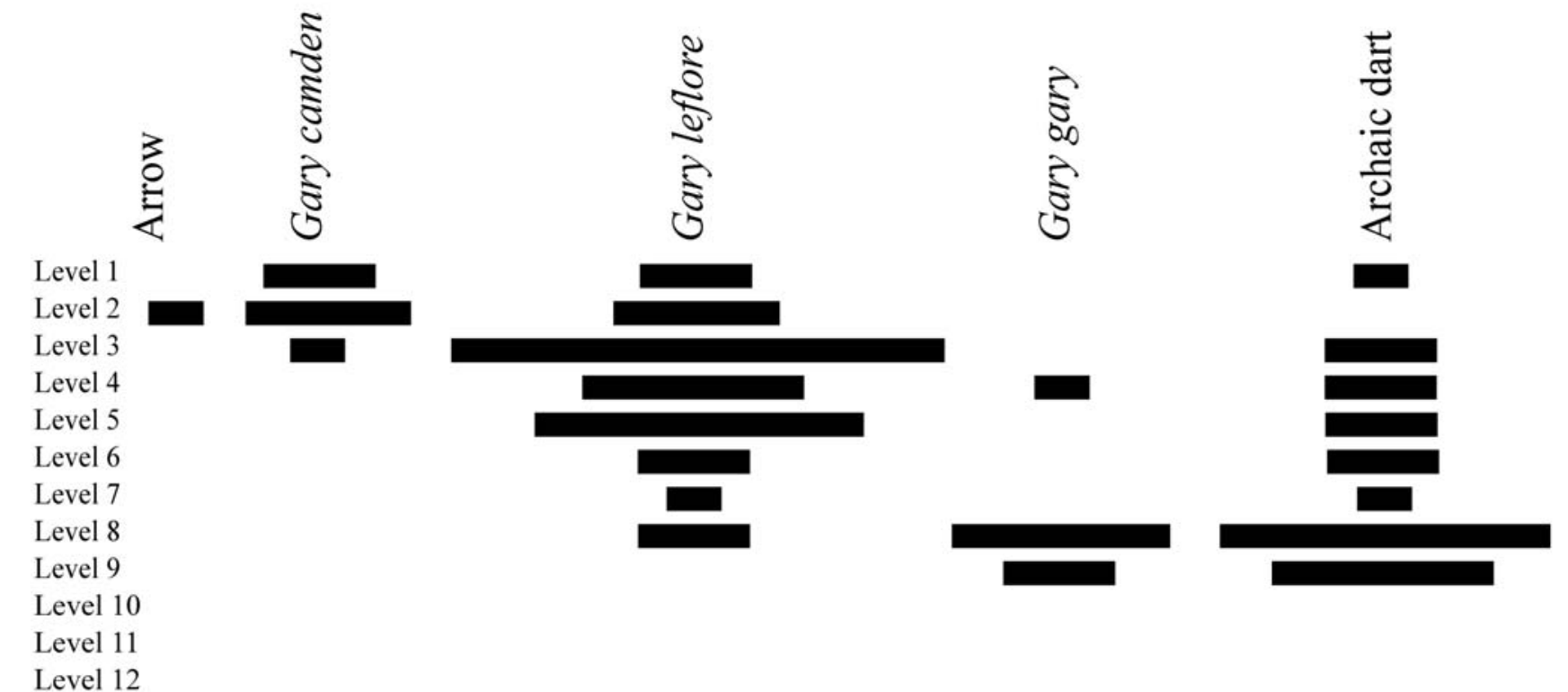

Key: $=$ Count of 1

Figure 8. Battleship Graph of the Williams I Seriation of Point Frequency by Class. 
The pottery types also proved to be temporally sensitive. In this research I separated the grog-bone temper sherds as a new type Williams Boneware, because Galm (1984) and others have suggested that the addition of bone to the temper of Williams Plain may have a temporal significance. Figure 9 presents the results of the correspondence analysis for the pottery types.

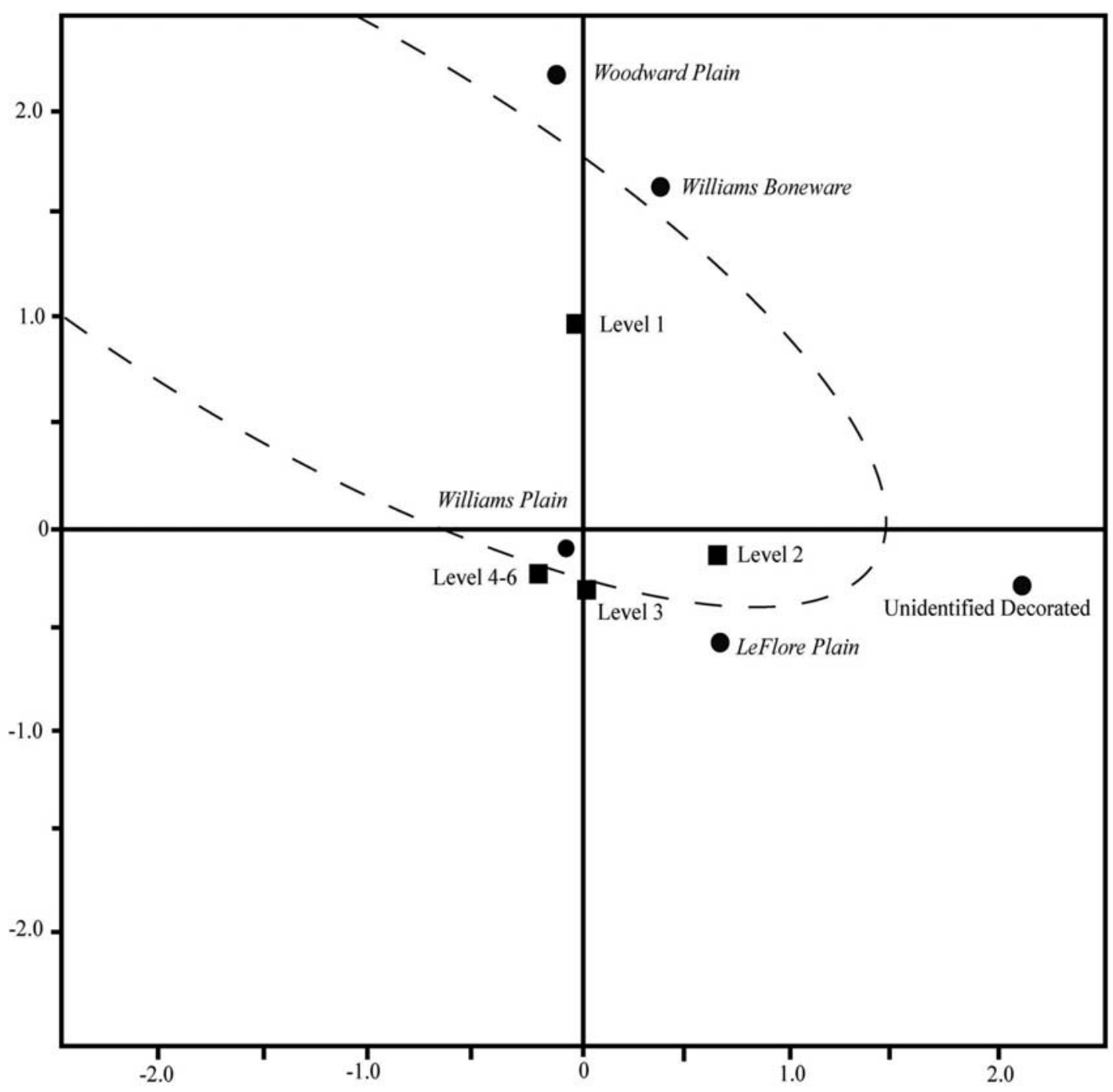

Figure 9. Results of the Williams I Pottery Type Correspondence Analysis (the horseshoe is read from bottom left, oldest, to top right, youngest).

Williams Plain dominates the assemblage in both percentage and frequency (Figures 10 to 11), but the frequency data removes the inflation seen in the initial adoption of pottery technology (the presence of only Williams Plain pottery). This can be seen especially well in levels 4 though 6 where Williams Plain represents $100 \%$ of the assemblage but is only represented by one, eight and one sherd respectively. It is interesting to note that LeFlore Plain appears to be earlier that Williams Boneware. The Indeterminate Decorated could represent the initial influence of Coles Creek (a hallmark of the Late Woodland cultural period, Evans phase as per Brown 1971) but the sherds were too small to definitively identify. The single sherd located in level five likely represents a disturbed context. 


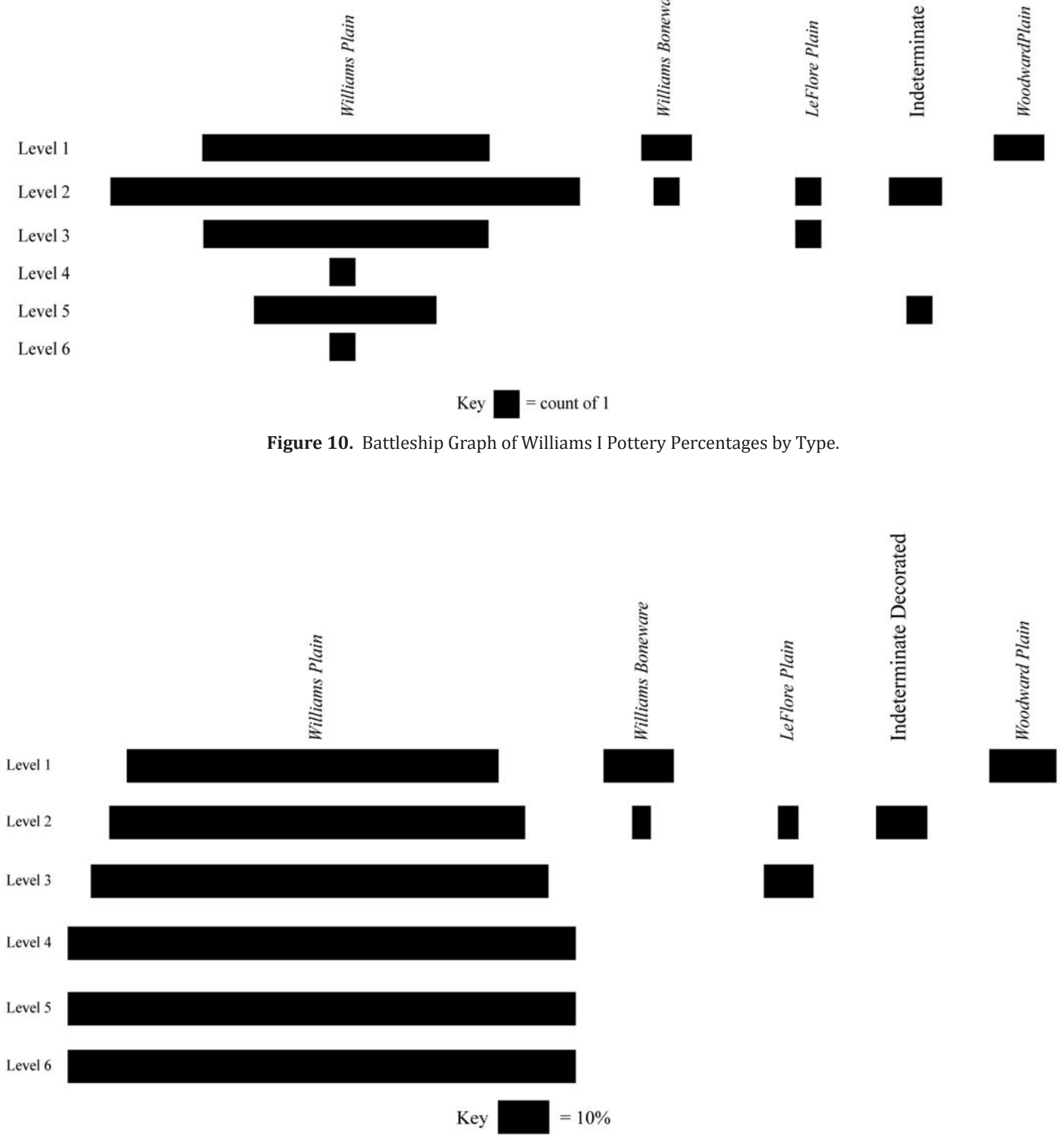

Figure 11. Battleship Graph of the Williams I Pottery Frequency by Type. 
The pottery distributions suggest four temporal breaks. First, Level 6 represents the initial appearance of pottery technology, thus identifying an Early Woodland period. Second, LeFlore Plain pottery represents an addition of a new pottery technology at Level 3. Williams Boneware represents a second Middle Woodland division at Level 2, and finally the addition of Woodward Plain in level 1 identifies a technological change associated with the Late Woodland cultural period.

The chipped-stone axe/hoe category was also seriated but the results did not indicate a strong seriation. However, plotting of a Fordian battleship graph for the chipped-stone axe/hoes suggests some temporal significance. The potential problems with the seriation is likely tied to the fact that there are only two types, but the correspondence analysis does indicate two clusters with the stemmed hoes clustering with the deeper (older) levels and the double-bitted axe/hoes clustering with the upper (younger) levels (Figure 12).

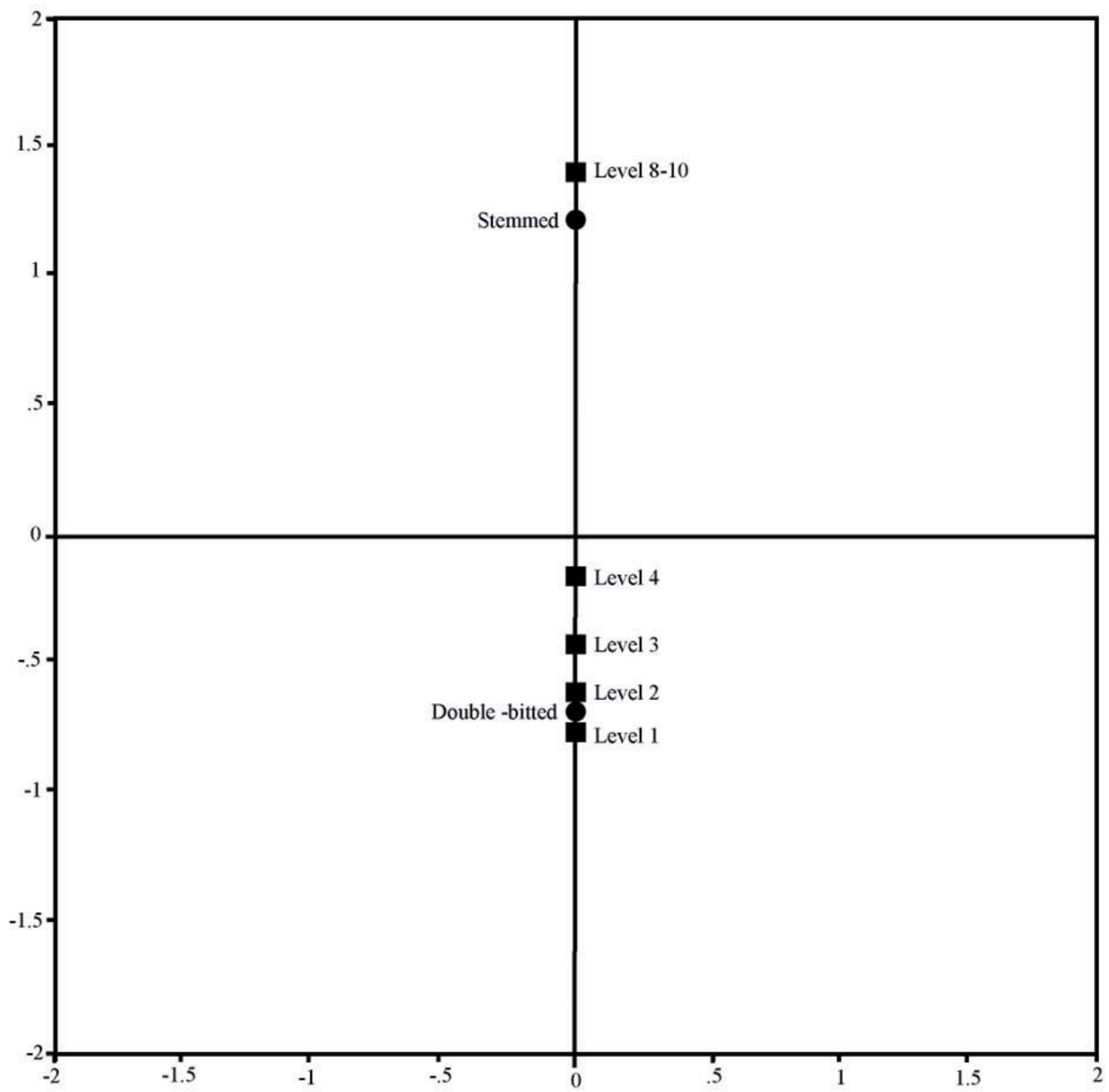

Figure 12. Williams I Axe/Hoe Correspondence Analysis Results Indicating Clustering.

The entire chipped-stone axe/hoe assemblage from the Williams I site (minus the surface and burial units) was analyzed. There appears to be a cultural preference for stemmed hoes during the Late Archaic cultural period. The appearance of double-bit axe/hoes corresponds to the Woodland period (beginning at Level 6) (Figure 13). The double-bitted axe/hoe in level 12 is likely due to mixing from intrusive burials. 


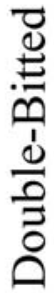

ত্ৰ

\section{Level 1}

Level 2

Level 3

Level 4

Level 5

Level 6

Level 7

Level 8

Level 9

Level 10

Level 11

Level 12

Key $\square=$ count of 1

Figure 13. Battleship Graph of the Williams I Chipped-Stone Axe/Hoe Frequency by Class.

Stemmed hoes are also present along side the double-bit variety into the Late Woodland period. These findings are interesting when compared to Galm's (1984) definition of the Wister and Fourche Maline phases. He does not describe the Wister phase people as using hoes and limits the double-bit variety to the Fourche Maline phase. The association of stemmed hoes with the Wister phase may indicate some degree of garden tending during the Late Archaic cultural period.

When all of the artifact types are viewed together several technological switches or changes are noted that may be good clues for dividing the traditional Fourche Maline phase (Figure 14). The results indicate five intervals of occupation at the site, four of these appear to be associated with the Woodland period, and one with the Late Archaic. The uppermost level (Level 1) appears to be associated with a Late Woodland (Evans phase) occupation as indicated by the presence of shell-tempered (Woodward Plain) vessels. 


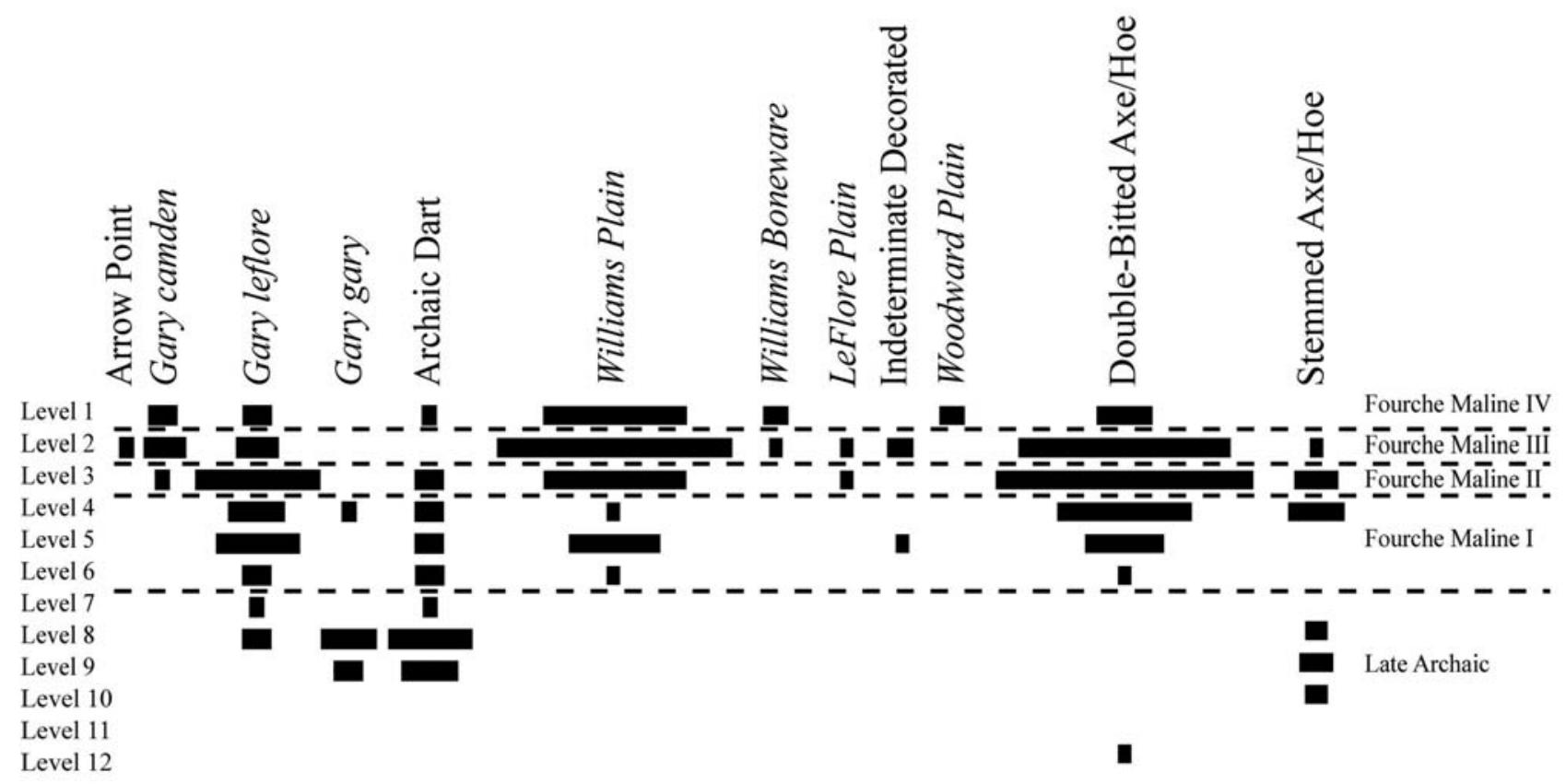

Key: $\mathbf{a}=$ Count of 1

Figure 14. Battleship Graph of the Entire Williams I Seriation Assemblage Frequency by Class.

The presence of arrow points, the initial appearance of Williams Boneware, and the Indeterminate Decorated pottery identifies a second Woodland occupation (Level 2) associated with the later part of Galm's (1984) Fourche Maline phase. Basically there is a shift in hunting technology associated with the bow and arrow, and apparent influences from the Lower Mississippi Valley (Coles Creek) culture as witnessed by the decorated sherds.

A third Woodland occupation is identified at Level 3, where Gary camden points and the initial use of LeFlore Plain pottery appear. A fairly long Early Woodland occupation (Levels 4 through 6) is identified based on the adoption of Williams Plain pottery, an increase in the use of Gary leflore points, and the initial use of double-bitted axes/hoes. Finally, the earliest occupation at the Williams I site is non-ceramic Late Archaic (Wister phase). The artifacts associated with this occupation are Gary gary points, several varieties of notched and stemmed dart points, the use of stemmed hoes, and the lack of pottery.

In order to test the findings from the initial seriation, two other groups of units were selected, one from the east central portion of the Williams I midden mound and one from the western portion of the mound for supplemental seriations (see Figure 1). Again units without burials were selected to avoid possible mixing of artifacts. The findings from these units closely mirror the initial seriation (Figure 15). 


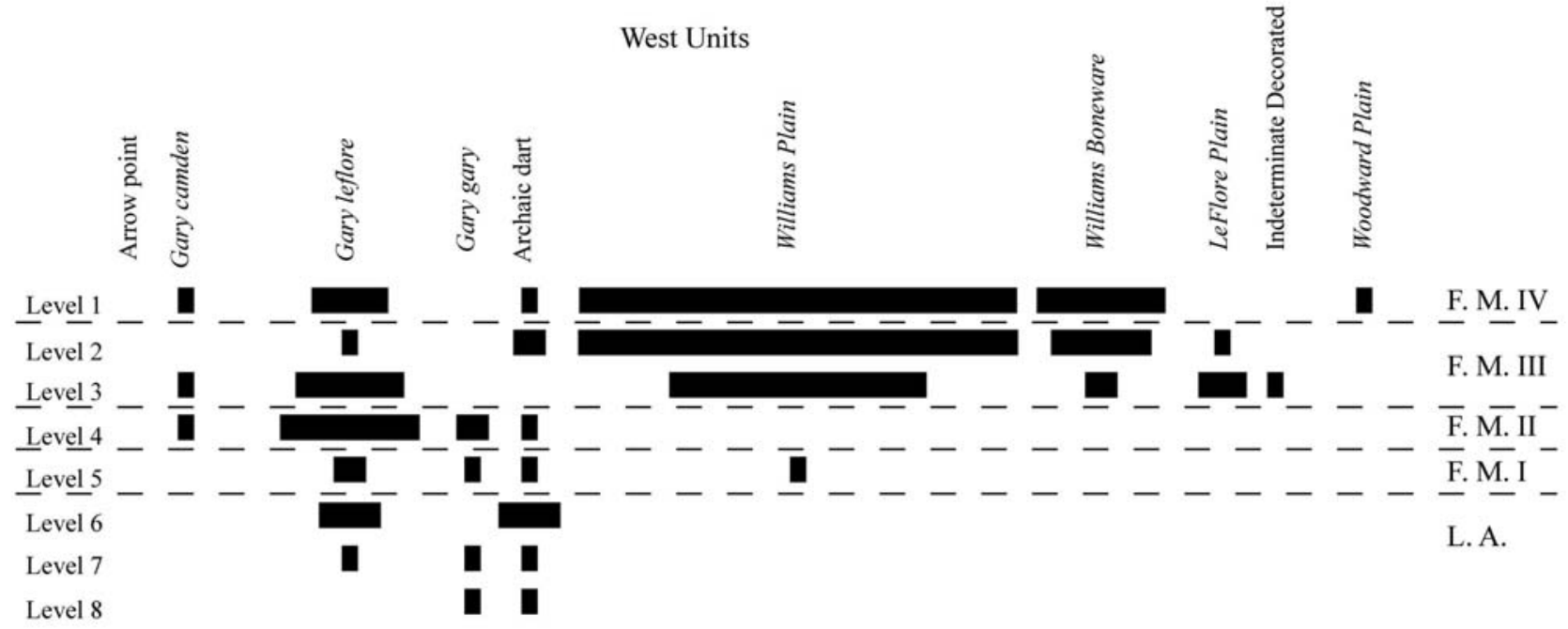

East Units

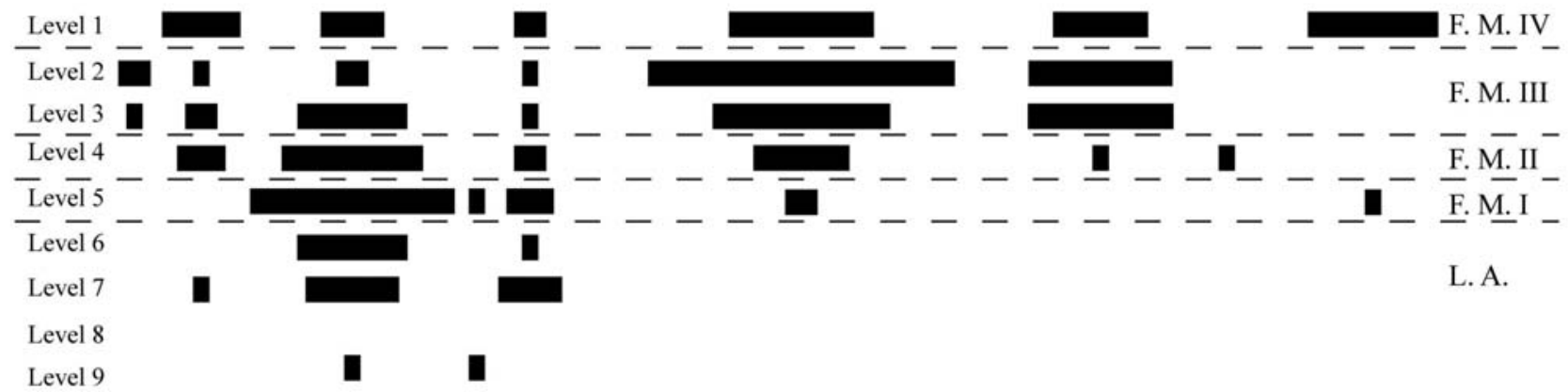

Key: $\mathbf{\square}=$ Count of 1

Figure 15. Battleship Graphs of the Alternate Seriations from the Williams I Site.

The difference in the thicknesses of the occupation levels in the second seriation is likely tied to the contour of the midden-mound as units near the center are close to one foot higher in elevation than units located closer to the edge of the mound. However, this being said the artifact distributions looked similar. The Late Woodland occupation was limited to the upper six inches. Below this was a second Woodland occupation was identified by the presence of arrow points, Williams Boneware, and the Indeterminate Decorated wares. This occupation appears to be six inches thicker than the initial seriation from the center of the midden mound, but again this is likely due to the contour of the mound.

Below this is a third, thin, Woodland occupation identified by the presence of Gary camden and LeFlore Plain. The Early Woodland/Late Archaic boundary identified with the initial use of pottery is between Levels 5 and 6, indicating that the Early Woodland occupation debris was concentrated more toward the center of the mound where it is close to 18 in $(46 \mathrm{~cm})$ thick. Finally the levels below this are Late Archaic (Wister phase).

A strong correlation appears between the seriations with the occupations thicknesses varying slightly as one progress from the center of the midden out to the edges. These findings are slightly at odds with Irvine's (1980) occupation horizons from the Williams I site. Based on her pottery analysis Levels 1 through 3 were Mississippian, Level 4 was Late Woodland (Evans phase), Levels 5 and 6 were Fourche Maline phase and below 
Level 6 the cultural horizon was associated with the Wister phase. The problem with Irvine's (1980) chronology is that the decorated sherds from Williams I represents only $3 \%$ of the entire pottery assemblage at the site, and $79 \%$ of these decorated sherds are likely affiliated with Woodland cultural period variety (Willaims Incised). This indicates that Irvine's (1980) identification of a Mississippian occupation is not well supported and strengthens the argument for identifying the upper 18 in $(46 \mathrm{~cm})$ as Woodland rather than a Mississippian component. Redefining Irvine's (1980) Mississippian as Woodland corresponds well with the seriation conducted here.

\section{Discussion}

The seriation results indicate that changes in material culture can be used as temporal markers to divide the roughly 2,400 year Arkansas Valley Formative Caddoan into more manageable and reasonable phases than Galm's (1984) two phase (Wister and Fourche Maline) scheme. Galm (1984:215) noted that his phases were long lasting $(\sim 1,200$ years each) and in the future could and should be refined into smaller units. I am interested in the dynamics of the Woodland period and will not focus on the Wister phase other than to say there are continuities between the Late Archaic and Woodland people and that stemmed hoes need to be added to the material culture list and finally, that Gary gary points are solely Late Archaic.

Following Galm (1984:215), the seriations indicate that there are adequate changes in material culture to break the Woodland period into four sub-periods (Fourche Maline I through IV) (Table 3).

Table 3. Revised Oklahoma Fourche Maline Chronology.

\begin{tabular}{|c|c|c|c|c|}
\hline & Oklahoma & Arkansas (Arkoma Basin) & $\begin{array}{c}\text { Arkansas (Misissippi Alluvial } \\
\text { Plain) }\end{array}$ & $\begin{array}{c}\text { Texas (Gulf } \\
\text { Coastal Plain) } \\
\end{array}$ \\
\hline Time Period & Period & Period & \begin{tabular}{|c|} 
Period \\
\end{tabular} & Period \\
\hline A.D. 1700 & \multirow{7}{*}{ Caddoan } & \multirow{7}{*}{ Caddo } & \multirow{7}{*}{ Mississippian } & \multirow{6}{*}{ Caddoan } \\
\hline A.D. 1600 & & & & \\
\hline A.D. 1500 & & & & \\
\hline A.D.1400 & & & & \\
\hline A.D. 1300 & & & & \\
\hline A.D. 1200 & & & & \\
\hline A.D. 1100 & & & & \multirow{3}{*}{ Formative Caddoan } \\
\hline A.D.1000 & \multirow{2}{*}{ Fourche Maline IV } & \multirow{2}{*}{ Caddo/Gober Complex } & Coles Creek & \\
\hline A.D.900 & & & \multirow{3}{*}{ Plumb Bayou/Coles Creek } & \\
\hline A.D. 800 & \multirow{3}{*}{ Fourche Maline III } & \multirow{3}{*}{$\begin{array}{l}\text { Late Fourche Maline/Gober } \\
\text { complex }\end{array}$} & & \multirow{3}{*}{$\begin{array}{l}\text { Late Fourche } \\
\text { Maline }\end{array}$} \\
\hline A.D.700 & & & & \\
\hline A.D.600 & & & \multirow{3}{*}{ Plumb Bayou/Baytown } & \\
\hline A.D. 500 & \multirow{3}{*}{ Fourche Maline II } & \multirow{3}{*}{$\begin{array}{l}\text { Middle Fourche Maline/Gober } \\
\text { complex }\end{array}$} & & \multirow{5}{*}{$\begin{array}{l}\text { Middle Fourche } \\
\text { Maline }\end{array}$} \\
\hline A.D. 400 & & & & \\
\hline A.D.300 & & & \multirow{2}{*}{ Marksville } & \\
\hline A.D.1 & \multirow{3}{*}{ Fourche Maline I } & Middle Fourche Maline & & \\
\hline 100 B.C. & & 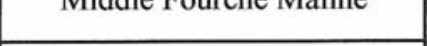 & \multirow{3}{*}{ Tchefuncte } & \\
\hline 300 B.C. & & \multirow{2}{*}{ Early Fourche Maline } & & Early Fourche \\
\hline B.C. $300+$ & & & & Maline \\
\hline
\end{tabular}


The material culture identifying the Early Woodland (Fourche Maline I) is the adoption of pottery technology (mostly Williams Plain, with some Williams Incised), the presence of only Gary leflore for the large contracting stem biface type, and the shift to double-bitted axe/hoes. Fourche Maline II incorporates a development of a dart/arrow transitional point type (Gary camden), the continued use of Gary leflore (likely as knives and dart points), continued use of double-bitted axes/hoes, and the addition of the grog/grit tempered (LeFlore Plain) to the pottery assemblage. Fourche Maline III is associated with the adoption of bow and arrow technology (as seen in the presence of small corner-notched arrow points), the continued presence of Williams Plain and LeFlore Plain with the addition of Williams Boneware pottery, and again, the use of double-bitted axes/hoes. Finally, the Late Woodland (Fourche Maline IV) is identified by an increase in decorated pottery, the appearance of shell tempered (Woodward Plain) as well as an increase in various arrow point forms. It should also be noted that there are stemmed hoes present in some of the Woodland cultural horizons but at a much lower frequency than the double-bitted axe/hoes. Archaic (stemmed and notched) dart points are also present through all the Woodland occupations in very low frequencies ( 1 to 2 ). These may represent either some degree of mixing in the units examined, heirloom/interesting finds, or both.

\section{Summary and Conclusions}

This paper addresses the origin and problems with the traditional concept of Fourche Maline and whether there are changes in material culture that could allow us to refine the chronology. The answer to this question based on the examination of one thoroughly excavated site is yes. The identification of temporally sensitive material culture types allow a refinement of the chronology for the Fourche Maline drainage and will help in refining the chronology in other drainages. Also an understanding of the material culture changes over time will help to identify occupations from the many Archaic, Woodland, and Mississippian surface collections in

Oklahoma. The refinement of the chronology is crucial to testing the hypothesis that Fourche Maline represents transegalitarian, complex hunter-gatherer-horticulturalists, because it prevents mistaking temporal changes as cultural changes. This will allow better finer-grained resolution of cultural changes, such as subsistence, over time.

This research represents much needed rethinking about the Fourche Maline culture in Oklahoma. The results of this study bring Oklahoma's view of Fourche Maline into line with the surrounding states (Table 4). This is important, because it will facilitate transfer of information and ideas as it clarifies or removes problematic terminology and jargon. 
Table 4. Revised Fourche Maline Chronology in Comparison to Surrounding States.

\begin{tabular}{|c|c|c|c|}
\hline Time Period & Phase & Period & Culture \\
\hline A.D. 1700 & \multirow{3}{*}{$\begin{array}{l}\text { Ft. Coffee } \\
\text { phase }\end{array}$} & \multirow{7}{*}{ Mississippian } & \multirow{7}{*}{ Caddoan Culture } \\
\hline A.D. 1600 & & & \\
\hline A.D. 1500 & & & \\
\hline A.D. 1400 & \multirow{2}{*}{ Spiro phase } & & \\
\hline A.D. 1300 & & & \\
\hline A.D. 1200 & \multirow{2}{*}{ Harlan phase } & & \\
\hline A.D. 1100 & & & \\
\hline A.D. 1000 & \multirow{2}{*}{ Evans phase } & \multirow{10}{*}{ Woodland } & Fourche Maline \\
\hline A.D. 900 & & & \\
\hline A.D. 800 & \multirow{3}{*}{ Akers phase } & & \multirow{3}{*}{$\begin{array}{c}\text { Fourche Maline } \\
\text { III }\end{array}$} \\
\hline A.D. 700 & & & \\
\hline A.D. 600 & & & \\
\hline A.D. 500 & \multirow{3}{*}{ Scott phase } & & \multirow{3}{*}{$\begin{array}{l}\text { Fourche Maline } \\
\text { II }\end{array}$} \\
\hline A.D. 400 & & & \\
\hline A.D. 300 & & & \\
\hline A.D. 1 & \multirow{2}{*}{ Williams phase } & & \multirow{2}{*}{ Fourche Maline I } \\
\hline 300 B.C. & & & \\
\hline 1,500-300 B.C. & Wister Phase & Late Archaic & \\
\hline
\end{tabular}

Fourche Maline in Oklahoma is now identified as a wholly Woodland period culture as it is in neighboring states. It elevates the term Fourche Maline in Oklahoma from a phase designator to a cultural or tradition level as it is used in neighboring states. The removal of Fourche Maline as a phase name allows future development of drainage specific designators as Willey and Phillips (1958) originally intended. The former Fourche Maline phase that was more a sub-period has been divided into three phases lasting more reasonable amounts of time. These divisions were based on chronologically sensitive material culture changes. Along with splitting Fourche Maline phase, I have proposed the revival of the Evans Phase as representing Late Woodland period occupations. I believe that the Evans phase has applicability and allows for a more smooth transition between the Fourche Maline and Caddoan Mississippian traditions. 


\section{References Cited}

Baxter, Michael

2003 Statistics in Archaeology. Hodder Arnold. London.

Bell, Robert E.

1953 The Scott Site, LeFlore County Oklahoma. American Antiquity 18:314-331.

1980 Fourche Maline: An archaeological Manifestation in Eastern Oklahoma. In Caddoan and Poverty Point Archaeology: Essays in Honor of Clarence Hungerford Webb. edited by J. L. Gibson, Louisiana Archaeology, Bulletin of the Louisiana Archaeological Society 6:83-125.

Bell, Robert E. and David A. Baerreis

1951 A Survey of Oklahoma Archaeology. Bulletin of Texas Archaeological and Paleontological Society 22:7-100.

Brown, James A.

1971 Pottery Vessels. Spiro Studies Vol. 3. University of Oklahoma Research Institute, Norman.

Burnett, Barbara A.

1990a The Bioarcheological Synthesis. In Human Adaptation in the Ozark and Ouachita Mountains. edited by G. Sabo III, A.M. Early, J.C. Rose, B.A. Burnett, L. Vogele Jr., and J.P. Harcourt, pp 71-192, Arkansas Archeological Survey Research Series No. 31, Arkansas Archeological Survey, Fayetteville.

1990b The Bioarcheological Synthesis of the Eastern Portion of the Gulf Coastal Plain. In The Archeology and Bioarcheology of the Gulf Coastal Plain: Volume 2. edited by D.A. Story, J.A. Guy, B.A. Burnett, M.D. Freeman, J.C. Rose, D. G. Steele, B.W. Olive, and Karl Reinhard, pp 385-418. Arkansas Archeological Survey Research Series No. 38. Arkansas Archeological Survey, Fayetteville.

Burns, Stephanie

1994 Bioarchaeology of the Mackey Site. Unpublished Masters Thesis, Department of Anthropology, University of Oklahoma.

Bruseth, James E.

1998 The Development of Caddoan Polities along the Middle Red River Valley of Eastern Texas and Oklahoma. The Native History of the Caddo, Edited by T. K. Perttula and J. E. Bruseth, pp. 47-68. University of Texas at Austin, Texas Archeological Research Laboratory, Studies in Archeology 30.

Davis, E. Mott

1961a Proceedings of the Fourth Conference on Caddoan Archaeology. Bulletin of the Texas Archaeological Society. 30:1-33.

1961b Proceedings of the Fifth Conference on Caddoan Archeology. Bulletin of the TexasArcheological Society 31:77-143.

Galm, Jerry R.

1981 Prehistoric Adaptations-Wister Valley. Unpublished Ph.D. dissertation. Washington State University. 1984 Arkansas Valley Caddoan Formative: The Wister and Fourche Maline Phases. In Prehistory of Oklahoma, edited by R. E. Bell, pp. 199-219. Academic Press, New York. 
Galm, Jerry R. and Peggy Flynn

1978 The Cultural Sequences at the Scott (34LF11) and Wann (34LF27) sites in the Prehistory of the Wister Valley. Research Series No. 3, Archaeological Research and Management Center. University of Oklahoma, Norman.

Guilinger, Edwin W.

1971 The Archaeological Situation at the Copeland Site, A Fourche Maline Site in LeFlore County. Master's Thesis, Department of Anthropology, University of Oklahoma.

Harmon, Anna M., and Jerome C. Rose

1989 Bioarcheology of the Louisiana and Arkansas Study Area. In Archeology and Bioarcheology of the Lower Mississippi Valley and Trans-Mississippi South in Arkansas and Louisiana. edited by M.D. Jeter, J.C. Rose, G.I. Williams Jr., and A.M. Harmon. pp. 323-354. Arkansas Archeological Survey Research Series No. 37. Arkansas Archeological Survey, Fayetteville.

Harrington, M.R.

1920 Certain Caddo Sites in Arkansas. Indian Notes and Monographs, New York Museum of American Indian/Heye Foundation, New York.

Irvine, Marilee

1980 Ceramic Analysis from the Williams I Site (34Lf24), Le Flore County, Oklahoma. Unpublished Masters Thesis, Department of Anthropology, University of Oklahoma.

Krieger, Alex D.

1947 The First Symposium on the Caddoan Archaeological Area. American Antiquity 13:198-207.

Moore, Clarence B.

2003 Some Aboriginal Sites On the Red River. In The Louisiana and Arkansas Expeditions of Clarence Bloomfield Moore, edited by R. A. Weinstein, D. B. Kelly and J. W. Saunders, pp. 395-566. University of Alabama Press, Tuscaloosa.

Newkumet, Phil J.

1940 Preliminary Report on Excavation of the Williams Mound, Le Flore County, Oklahoma. The Oklahoma Prehistorian 3(2):2-10.

Orr, Kenneth G.

1946 The Archaeological Situation at Spiro, Oklahoma; A Preliminary Report. American Antiquity 11: 228-232+235-256.

1952 Survey of Caddoan Area Archaeology. Archaeology of the Eastern United States, edited by J. B. Griffin, pp. 239-255. University of Chicago Press, Chicago.

Picarella, A. E.

1999 The Otter Creek Site and the Fourche Maline Phase of Southeastern Oklahoma. Bulletin of the Oklahoma Anthropological Society 48:1-50. 
Powell, Mary L., and J. Daniel Rogers

1980 Bioarchaeology of the McCutchan-McLaughlin (34Lt11) Site: Biophysical and Morturary Variability in Eastern Oklahoma. Studies in Oklahoma's Past No.5. Oklahoma Archaeological Survey, Norman.

Proctor, Charles

1957 The Sam Site, Lf-28, of LeFlore County, Oklahoma. Bulletin of the Oklahoma Anthropological Society 5:45-92.

Rose, Jerome C. and Anna M, Harmon

1989 History of Bioarcheology and Bioarcheological Resources. In Archeology and Bioarcheology of the Lower Mississippi Valley and Trans-Mississippi South in Arkansas and Louisiana. edited by M.D. Jeter, J.C. Rose, G.I. Williams Jr., and A.M. Harmon. pp. 291-322. Arkansas Archeological Survey Research Series No. 37. Arkansas Archeological Survey, Fayetteville.

Rose, Jerome C., and Barbara A. Burnett

1990 Bioarcheology of the Eastern Portion of the Gulf Coastal Plain. In The Archeology and Bioarcheology of the Gulf Coastal Plain: Volume 1. edited by D.A. Story, J.A. Guy, B.A. Burnett, M.D. Freeman, J.C. Rose, D. G. Steele, B.W. Olive, and Karl Reinhard, pp 132-148. Arkansas Archeological Survey Research Series No. 38. Arkansas Archeological Survey, Fayetteville.

Rose, Jerome C., James P. Harcourt, and Barbara A. Burnett

1999a Bioarcheology of the OAO Study Area. In Human Adaptation in the Ozark and Ouachita Mountains. edited by G. Sabo III, A.M. Early, J.C. Rose, B.A. Burnett L. Vogele Jr., and J.P. Harcourt , pp 71-192, Arkansas Archeological Survey Research Series No. 31, Arkansas Archeological Survey, Fayetteville.

Rose, Jerome C., Barbara A. Burnett, and James P. Harcourt

1999b Ouachita Mountains, Arkansas River Valley and Ozarks Mountains. In Bioarcheology of the South Central United States. edited by J.C. Rose, pp 1-34. Arkansas Archeological Survey Research Series No. 55, Arkansas Archeological Survey, Fayetteville.

Rowe, Simone B.

2009 The Akers Site (34Lf32): Preliminary Bioarchaeology of a Fourche Maline Site. Unpublished Master's Thesis, Department of Anthropology, University of Oklahoma.

Schambach, Frank F.

1982 An Outline of Fourche Maline Culture in Southwest Arkansas. Arkansas Archeology in Review, edited by N.L. Turbowitz and M. D. Jeter, pp. 76-197.

1998 Pre-Caddoan Cultures in the Trans-Mississippi South. Arkansas Archeological Survey Research Series, 53.

2002 Fourche Maline: A Woodland Period Culture of the Trans-Mississippi South. In The Woodland Southeast, edited by R.C. Mainfort Jr. and D. G. Anderson, pp. 90-112. University of Alabama Press, Tuscaloosa.

Sharrock, Floyd W.

1960 The Wann Site, Lf-27, of the Fourche Maline Focus. Bulletin of the Oklahoma Anthropological Society 8:17-47. 
Vehik, Rain

1982a The Archaeology of the Bug Hill Site (34PU116): Pushmataha County, Oklahoma. Research Series No. 7, Archaeological Research and Management Center, The University of Oklahoma, Norman.

1982b Phase II Archaeological Investigations at Clayton Lake, Southeast Oklahoma. Research Series No. 8, Archaeological Research and Management Center, The University of Oklahoma, Norman.

Willey Gordon R. and Philip Phillips

1958 Method and Theory in American Archaeology. University of Chicago Press, Chicago.

Wyckoff, Don G.

1980 Caddoan Adaptive Strategies in the Arkansas Basin, Eastern Oklahoma. Unpublished Ph.D. Dissertation, Department of Anthropology, Washington State University. 